\title{
Cultural Sustainability and the SDGs: Strategies and Priorities in the European Union Countries
}

\author{
By Susanna Ferran Vila ${ }^{1}$, Giorgia Miotto ${ }^{2}$, Josep Rom Rodríguez ${ }^{3}$
}

\begin{abstract}
This research aims to analyze how the Sustainable Development Goals (SDGs) are included in the EU cultural policies and which are the priorities of the European Union (EU) in the cultural sustainability's agenda. We performed a content analysis of the EU Countries' cultural policies, evaluating the grade of inclusion of the SDGs. The conclusions show that the EU cultural policies, although not explicitly, include the SDGs in the definition of their strategies, policies, projects and actions. Specifically, eight of the seventeen SDGs are included in relation to the following interdisciplinary topics: Cultural and Natural Heritage (SDG11), Cultural Education (SDG 4), Cultural Diversity (SDG 4), Social Inclusion (SDG 10), Information Access (SDG 16), Cooperation with other institutions (SDG 17), Environment (SDG 13), Economic Growth (SDG 8) and Gender Equality (SDG 5). Topics' priorities are generally commonly defined in the different EU countries.
\end{abstract}

Keywords: European Union, Cultural sustainability, cultural policy, sustainable development, SDGs, Agenda 2030

\section{Introduction}

Sustainability, defined as the "development that meets the needs of the present without compromising the ability of future generations to meet their own needs" (Brundtland et al., 1987, p.23) is the new paradigm in the XXI contemporary world (Turner, 2017). With the main objective of improving sustainability in all its dimensions, in 2015 the United Nations (hereinafter UN) adopted the 2030 Agenda, which is an "action plan for people, planet and prosperity addressed to all world countries, regardless of their level of development, with the intention of eradicating poverty, protecting the planet, strengthening universal peace and access to justice" (United Nations, 2016c). The 2030 Agenda contained 17 Sustainable Development Goals (hereinafter SDGs) distributed in 169 specific targets and organized in five dimensions. The first three dimensions People, Planet and Prosperity are also known as the Triple Bottom Line or the 3Ps, and they were identified by Elkinton (1998) as the pillars of the sustainable development (Elkinjton, 1998). People is the human capital, Planet the practices that do not compromise environmental resources for future generations and Profit focuses on the economic impact of any action (Alhaddi, 2015). Even so, since the 2030 Agenda approval, two more dimensions have been integrated: Partnership, which strengthens the stakeholder's

\footnotetext{
$\mid{ }^{1}$ Blanquerna School of Communication and International Relations, Ramon Llull University, Barcelona, Spain

${ }^{2}$ Blanquerna School of Communication and International Relations, Ramon Llull University, Barcelona, Spain; *Corresponding Author

${ }^{3}$ Blanquerna School of Communication and International Relations, Ramon Llull University, Barcelona, Spain
} 
capacity to work together, and Peace, which together with justice and institutions are essentially complementary to the three central dimensions (Wiktor-Mach, 2018). For years, since the publishing of the Brundtland report (Brundtland et al., 1987), the sustainability concept has been linked mainly to the environmental dimension, nevertheless, in the last decade, scholars have been stating that sustainability refers to policies and actions oriented towards realizing sustainable development of the natural environment, society, and economy, evaluating the impact of any action into these three dimensions (Miotto et al., 2020; Tollin \& Christensen, 2019).

From the cultural perspective, historically, the role of culture has been claimed as one more pillar or dimension of sustainability (Hawkes, 2001; UCLG, 2015). According to John Hawkes: "The initial strategies that need to be implemented to successfully achieve sustainability must be cultural ones" (Hawkes, 2001, p. 12). Nevertheless, the main cultural actors, as for example the UNESCO, confirm that culture is still a 'missing pillar' of sustainability and its role is still limited (Throsby, 2017a; Turner, 2017; Wiktor-Mach, 2018).

In this article we aim to analyze how SDGs are included in the EU cultural policies, and which are the priorities of the EU in the cultural sustainability's agenda.

The objective is to contribute to the academic field of cultural sustainability, identifying the most relevant SDGs for the European agenda. According to Kagan (2019) it does exist a research field on cultural sustainability focused on several Humanities and Social Sciences areas and we aim to contribute to this research agenda to help policy makers and the cultural and creative industry to better align and focus their effort to succeed in the 2030 Agenda. According with the results and conclusions of the research we will propose some actions that the European Union could implement in order to help the European countries to achieve the 2030 Agenda's goals.

To define the concept of cultural sustainability we align ourselves with the approach of culture in/for/as sustainability proposed by Dessein, Soini, Fairclough, \& Horlings (2015), and by the UNESCO (2019) which relates to the transversal role of culture as a driver of sustainable development (Hereinafter SD). Dessein et al (2015) consider cultural sustainability from the perspective of intellectual and creative products and also as societal beliefs and practices. In this definition of cultural sustainability, culture includes the different forms of arts and of the creative industry. UNESCO, for its part, proposes that culture contributes transversally to each of the five dimensions of sustainability (people, planet, profit, peace, partnerships), and it proposes that it has an important role in driving the SD, contributing to create economic, ecological and social benefits (UNESCO, 2019b; Wiktor-Mach, 2018).

In this article we analyze the grade of inclusion of the SDGs into the EU cultural policies, considering cultural policies as the strategic basis of cultural sustainability. We performed a content analysis of how the SDGs are represented in the EU countries cultural policies. The conclusions show that the EU cultural policies, although not explicitly, include the SDGs in the creation of strategies, policies, projects and actions. The European Union has a great opportunity to boost these strategies and we propose a more relevant protagonism in this European journey through sustainability in general and, specifically, in the cultural dimension.

This article is organized as follows: first we perform the literature review focused on 
introducing the 2030 Agenda, and on proposing a framework for cultural sustainability and cultural policies in the European Union (hereinafter EU). Afterward, we present the methodology, the results and the discussion. We finalize with the research's conclusions, and we propose possible proactive actions for the EU and further future research lines.

\section{Literature Review}

\subsection{Introduction to the 2030 Agenda and the SDGs}

During the Sustainable Development Summit "Transforming our world" celebrated in 2015 the UN published the 2030 Agenda for SD, asking to all the UN member states to work together for a better and more just world. This Agenda organized around 17 major Goals, the SDGs, is an action plan in favor of people, planet and prosperity for all world countries, regardless of their level of development, and with the intention of strengthening universal peace and access to justice. This resolution recognizes that today's world challenge is the poverty eradication and the planet healing and environmental protection (United Nations, 2016c).

With the objective of achieving long-term global SD (United Nations, 2019b), the 2030 Agenda aims to involve the largest group of stakeholders, such as all the territorial actors, the local and regional governments, the private business sector, the financial sector, the knowledge and education industry and the whole organized civil society (Alburquerque Llorens, 2019). All the involved actors are relevant and necessary, nevertheless, according to Gusmão Caiado, Leal Filho, Quelhas, Luiz de Mattos Nascimento, \& Ávila (2018) there is a specific need to invest in education and information, political leadership and governance in both national and local governments, as in business. (Beyne, 2020; Gusmão Caiado et al., 2018).

The 17 SDGs are organized into 169 specific and integrated goals and 230 indicators that cover the economic, social, and environmental dimensions of SD. The whole 2030 Agenda objective is to reconcile the economic well-being, natural resources, and society, while avoiding compromising the possibility of life on the planet and the human species life quality (General Assembly of United Nations, 2015). The SDGs represent a new perspective of global governance, different from previous laws and regulations, which aims to overcome current negative global trends, thanks to the collaboration between different stakeholders at different levels, thus creating inclusive synergies that allow the SDGs multiple implementation (Saito et al., 2017). As proposed by Sanahuja \& Vázquez (2017) the SDGs have many potentialities, such as: conceiving development in a multidimensional and not just "economic" way, providing integrated and indivisible content of universal SD priorities, bringing together two converging agendas such as human development and SD, proposing a universal strategy, mobilizing the political role and global citizenship, and contributing to improve the provision of global public goods. But the same authors also add that these SDGs can have a series of risks, pointing out three especially relevant risks: the possibility of having a reductionist approach to a complex reality such as sustainable human development, a difficult way of evaluating each country's contribution to achieving global goals, and finally there is a risk of prioritizing purely quantitative development indicators (Sanahuja \& Vázquez, 2017).

If we take into consideration how 2030 Agenda is progressing, according to the report 
made by the UN General Secretariat on the SDGs evolution, we are alerted that "the shift in development pathways to generate the transformation required to meet the SDGs by 2030 is not yet advancing at the speed or scale required" (United Nations, 2019b, p.i). Especially now (2020) that "due to the COVID-19, an unprecedented health, economic and social crisis is threatening lives and livelihoods, making it even more difficult to achieve the SDGs" (United Nations, 2020, p.3). To overcome these obstacles, Sachs et al. propose bringing together the SDGs into six major necessary transformations with the goal of achieving the SDGs more efficiently (Sachs et al., 2019). These transformations are education, gender and inequalities; health, well-being and demographics; decarbonized energy and sustainable industry; sustainable food, land, water and oceans; sustainable cities and communities; and the digital revolution for SD.

\subsection{Cultural sustainability framework}

Research in cultural sustainability has highlighted that this concept should be treated as multidimensional and dynamic. According to Kangas, Duxbury, \& De Beukelaer (2017) "The concepts and frameworks that have evolved to situate culture in sustainability contexts have demonstrated multidisciplinarity, substantial flexibility, and a widening plurality of approaches over time"(Kangas et al., 2017b). According to Molina Neira we define cultural sustainability as:

"The manifestation and practice of traditional and new culture as a result of a constant creative process and free individual and collective expression that links the past and present in the artificial and natural physical space. It generates a dynamic that characterizes the solution of problems, ways of life, art, knowledge, tangible and intangible heritage and especially the identity that together form a legacy that is expected to reach the future" (Molina Neira, 2018, p. 6)

In this article we consider cultural sustainability from the culture perspective as "intellectual and creative products" and as "a societal beliefs and practices", but it is clear that cultural sustainability is also known as the fourth pillar by authors such as Soini \& Dessein (2016), Asikainen, Brites, Plebanczyk, Rogac mitjatovic, \& Soini, (2017) y Loach, Rowley, \& Griffiths (2017), among others. According to Culture Action Europe, "a cultural pillar is necessary for its value in the creation of collective narratives, its ability to consolidate communities and foster diversity as an essential element in sustainability" (Culture Action Europe, 2017). This position is also supported by other academics and institutions which claim that culture can offer answers to global challenges of today's world (Bervar, 2019; Hawkes, 2001; Nurse, 2006; Sabatini, 2019; UNESCO, 2013).

This commonly accepted approach narrows the definition of culture only within arts and creative-cultural industry, and it may devalue the connections to broader social and environmental issues (Astara, 2014). For this research, we consider that culture is not just a pillar of the SD, but a transversal dimension (UNESCO, 2018) since "Today, there is a growing awareness that culture plays many roles in sustainability” (Erlewein, 2017, p.1).

Cultural sustainability is also defined in the conceptual framework proposed by the European Association for Science and Technology and the COST.eu network through the Action IS1007 (Dessein et al., 2015). Culture is considered as part of the SD and a tool to reach it (Baltà Portolés \& Dragićevic Šešić, 2017; Dessein et al., 2015; Errichiello \& Micera, 2018; Kagan et al., 2018; Molina Neira, 2018; Rayman-Bacchus \& Radavoi, 2019; 
Swanson \& DeVereaux, 2017; Throsby, 2017b; Wiktor-Mach, 2018).

Table 1. Cultural Sustainability Theoretical Framework (Dessein et al. 2015)

\begin{tabular}{|l|l|}
\hline $\begin{array}{l}\text { Conceptual Framework “Culture in, for, } \\
\text { as SD" (Dessein et al. 2015) }\end{array}$ & Explanation \\
\hline Culture in Sustainability & $\begin{array}{l}\text { culture as another dimension of SD } \\
\text { Intellectual and creative products } \\
\text { Culture as a driver (UNESCO) }\end{array}$ \\
\hline Culture for Sustainability & $\begin{array}{l}\text { culture as a mediator between the environmental, } \\
\text { economic and social dimensions } \\
\text { society beliefs and practices } \\
\text { Culture as an enabler (UNESCO) }\end{array}$ \\
\hline Culture as Sustainability & $\begin{array}{l}\text { culture as a basis for SD } \\
\text { society beliefs and practices } \\
\text { Culture as an enabler (UNESCO) }\end{array}$ \\
\hline
\end{tabular}

Source: Owned elaboration based on Dessein et al. 2015

UNESCO affirms the role of culture as an enabler and driver of SD (Wiktor-Mach, 2018), considering culture as a tool for poverty reduction, job creation, social inclusion, sustainable urban development, and revitalization. Tangible and intangible heritage (monuments, traditions, unique identity, local cultural services, music, etc.) are useful, for example, for cultural tourism and to provide jobs and revenue to local people, including marginalized groups. Culture is a tool to mitigate the effects of climate change through each countries knowledge and cultural heritage (Barker, 2019; Wiktor-Mach, 2018).

Culture and the creative industry have the responsibility to safeguard and sustain cultural practices and rights; to 'green' the operations and impacts of cultural organizations and industries; to raise awareness and catalyze actions about sustainability and climate change; and to foster 'ecological citizenship' (Duxbury et al., 2017; Isar, 2017; Jeannotte, 2017; Loach et al., 2017; Maxwell \& Miller, 2017; Throsby, 2017).

\subsection{The Agenda 2030 and the cultural sustainability}

Culture and sustainability are necessary linked and relevant, nevertheless most academics underline the low impact of culture on the SDGs (Duxbury et al., 2017; Erlewein, 2017; Throsby, 2017a; Turner, 2017). Actually, "Often approaches that relate culture and development have been limited to statements of intent and have been impractical, which may explain their poor consideration and inclusion in public policies" (Martinell, 2020, p. 5). According to Throsby (2017) the SDGs definition did not take into account the relevant role of culture, focusing more in other aspects of the SD such as the environmental and the economic dimensions.

However, Culture is explicitly mentioned within the 2030 Agenda framework regarding education (SDG 4), sustainable cities (SDG 11), food security (SDG 2), environment (SDG 13), economic growth (SDG 8), sustainable consumption and production patterns (SDG 12), and peaceful and inclusive societies (SDG 17) (Erlewein, 2017; Streimikiene et al., 2019; Wiktor-Mach, 2018). In addition, SDG 17 encourages inclusive alliances in sectors such as culture that are not otherwise reflected in the 2030 Agenda (Luque Gallegos, 2015). The protagonism given to culture within this agenda is unparalleled and 
unprecedented within international agendas on development, as culture is now made explicit (Erlewein, 2017) .

According to the UNESCO: "The 2030 Agenda has opened up new avenues to integrate culture into policies for social and economic inclusion and environmental sustainability with innovative solutions that are state-owned" (UNESCO, 2018, p.3). The UNESCO has recently defined 22 thematic indicators to measure and monitor the progress of culture in the national and local SDGs implementation (Petti et al., 2020; UNESCO, 2019b) and the relationship between the value created by culture and the SDGs implementation is a frequent topic of research (Streimikiene et al., 2019).

\subsection{The cultural policies' current state and their relationship with the Sustainable Development in the EU}

Cultural policies are "understood as the promotion or prohibition of cultural practices and values by governments, corporations, other institutions and individuals" (International Journal of Cultural Policy, 2020). We refer to EU cultural policies, we mean the cultural policies of each member state, since, from a technical perspective, the EU does not have a common cultural policy, as it does in other areas where its competences go beyond national jurisdiction. In the case of culture, the principle of subsidiarity prevails, giving the power to the member states to have exclusive competence in making decisions and carrying out actions. Nevertheless, there are common cultural programs that promote culture in the EU, such as the Creative Cities program, the Media program or the European Capital of Culture, among others. (Xuereb, 2018).

In the EU countries, cultural policies have evolved a lot in the last 20 years. As a widespread trend, they have been decentralized, giving more power to regional, local, private sector and civil society authorities, ceasing to be conceived as an isolated sector to become an essential dimension of public action: "Since the adoption of the 2030 Agenda, the contribution of culture to SD has been more explicitly expressed in national and local cultural policies" (UNESCO, 2019a, p.11). Furthermore, with regard to cultural policies issues, the current trend shows that this has expanded beyond the protection of cultural heritage, the central axis of traditional European cultural policies. Nowadays cultural policies include cultural diversity, social inclusion, intangible heritage, cultural products and services such as economic growth, education and cultural diplomacy (UNESCO, 2019a, p.16).

These cultural policies rarely explicitly incorporate the concept of Sustainable Development and to counteract this situation, the EU, that has been working on Sustainable Development since the Amsterdam Treaty (1999), and that supports the 2030 Agenda, has recently approved a resolution that aims to develop an action plan about culture as a tool for SD (Council of the European Union, 2019).

Table 2: EU Council (2019) resolution on Culture and SD

EU Council (2019) resolution on Culture and SD

(1) Promoting the cultural dimension of SD

(2) Integrating cultural policies into SD strategies

(3) Reviewing cultural policies to maximize their contribution to sustainability

(4) Exchange information and good practices 


\section{EU Council (2019) resolution on Culture and SD}

(5) Include Culture in the Voluntary National Review Reports at the United Nations Political Forums

(6) Committing citizens, especially youth and children, and the cultural and creative sectors to participate in the integrated and active governance of culture and SD

(7) To work together with other European institutions and their publics of interest to unlock the high potential that culture has for sustainability, especially with the Development Commission for the creation of the action plan for the cultural dimension of SD

(8) To create, as soon as possible, a working group on the cultural dimension of SD (Council of the European Union, 2020)

Source: Own elaboration

\section{Research Methodology}

The main objective of this research is to analyze how EU cultural policies include SDGs references and to define which are the EU priorities within the 2030 Agenda in terms of culture. We carried out a content analysis of the EU member states cultural policies in relation to the SDGs. We demonstrate that, even though the SDGs are not explicitly cited, they are embedded in the content of the different cultural policies.

The analyzed documents for this study are the EU countries profiles created by the cultural policies experts and published in the Compendium of Cultural Policies \& Trends project. (Boekman Foundation, 2020). This project was initiated in 1998 by the European Council and the ERICarts Institute and is an online platform for information and monitoring of cultural policies in different countries in Europe and around the world. Currently, more than 100 cultural policy researchers from 43 different countries are collaborating on this project: "The Compendium plays a crucial role in developing knowledge, interaction and exchange in the global community regarding cultural policies" (Boekman Foundation, 2020). Each country has a public profile that contains information about their historical development in cultural policies, present structure, financial details, cultural industries, etc. The information presented in each country's profile comes from a variety of sources such as official documents from different governments, reports made by ministries, research studies, reports or manifestos made by lobbyists, statutes of artists and cultural producers, and also from political campaigns or the media (Boekman Foundation, 2020).

The analyzed country's profiles were the ones updated since the 2015. The sample that fulfilled this requirement included 18 of the $27 \mathrm{EU}$ countries: Austria, Belgium, Bulgaria, Croatia, Czech Republic, Finland, France, Germany, Hungary, Ireland, Italy, Lithuania, Malta, Poland, Slovakia, Spain and the Netherlands.

A content analysis were performed, as a set of interpretive procedures of communicative products (Piñuel Raigada, 2002) and a method to study and analyze communications in a systematic, objective and quantitative way (Noguero, 2002).

A semantic, qualitative and interpretative content analysis based on Coding was performed (Friese, 2011; Olabuénaga, 2012). The types of codes used were previously generated according to the previously designed theoretical framework (Holton \& Walsh, 2017; Trinidad-Requena et al., 2006). Two groups of codes were applied. One group was made by the 17 SDGs of the UN 2030 Agenda, to categorize the scope of sustainability in European cultural policies. Additionally, a second group of codes was added, in order to 
evaluate the grade of implementation identifying if the mentioned topics were policies, projects or actions. With this second coding we meant to evaluate the level of achievement and concreteness of each cultural proposal, considering policies as the most theoretical and abstract stage and the actions as the most tactical and practical one.

We analyzed the countries' reports published by culturalpolicies.net not older than five years from the time of the research and we performed a manual content analysis of the text, coding each paragraph with a tag. The codes/tags were pre-established since we used the actual 17 Sustainable Developing Goals defined by the UN. We associated a code/tag to each paragraph, assigning each part of the text to the related SDG. With this methodology, we could understand how often and with what intensity each country talks about policies, projects and actions, related to each of the 17 SDGs.

This methodology has also been used and tested previously in similar studies (Horne et al., 2020; Miotto et al., 2019).

\section{Results}

\subsection{Overall results}

Results show that the most referred SDGs in the EU countries cultural policies are: first the SDG 11 Sustainable cities and Communities; in the second place, SDG 4 Quality Education, and third SDG 10 Reduced Inequalities. Follow in decreasing order: SDG 17 Partnerships for the goals, SDG 16 Peace, Justice and Strong Institutions, SDG 13 Climate Action, SDG 8 Decent Work and Economic Growth and finally, SDG 5 Gender equality. The other SDG have no occurrence or are so minimal that they cannot be taken into account.

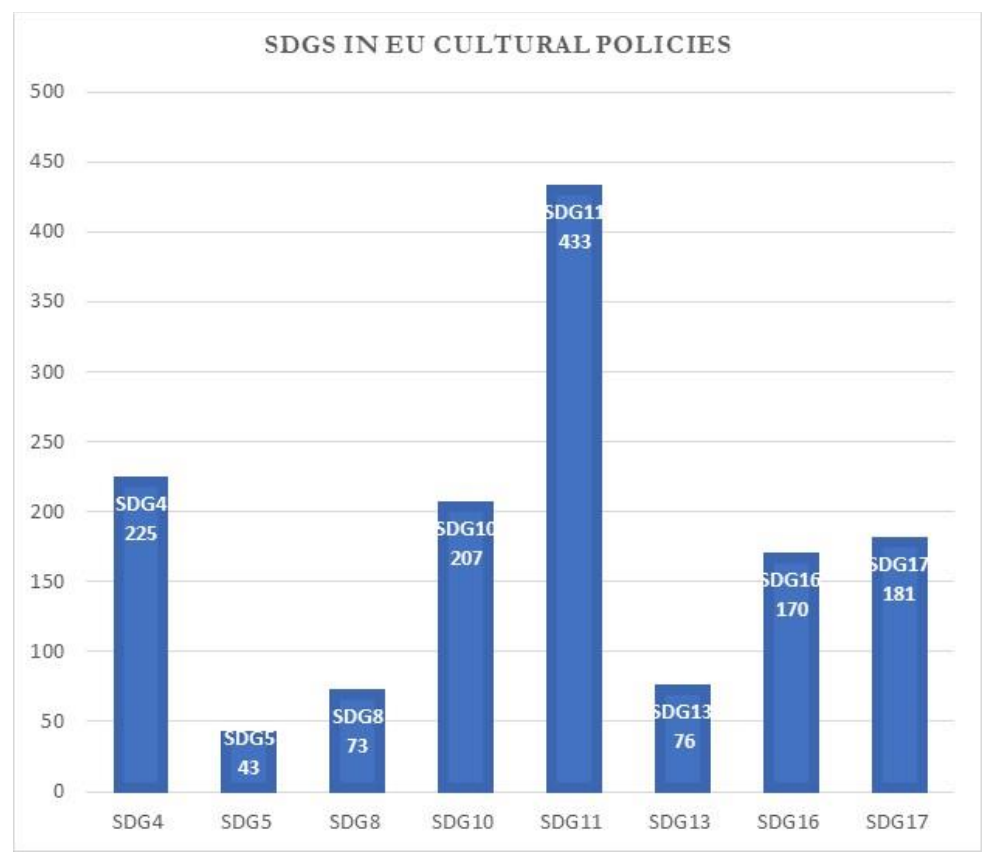

Figure 1: SDGs in EU Cultural Policies 
In relation to the grade of concreteness and implementation of the mentioned topics, results show that mostly they are presented in the form of policies, representing $67.48 \%$ of the total. The $28.64 \%$ are considered projects related to the SDGs and only the 3.88\% of the analyzed quotes described concrete and implemented actions (Fig. 2 and 3).

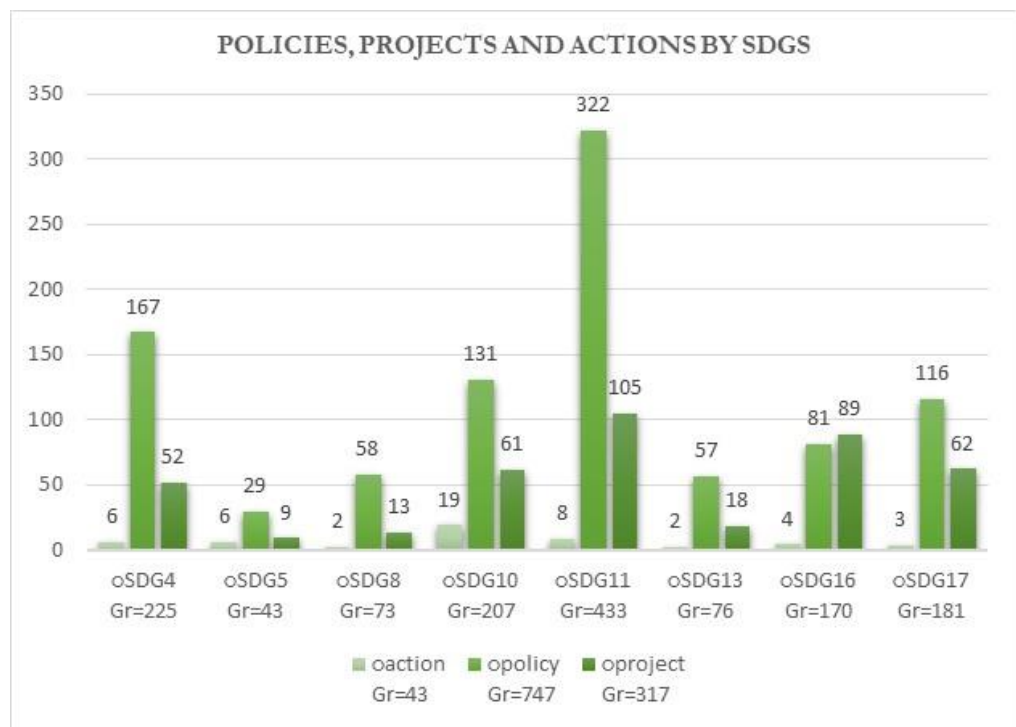

Figure 2: Policies, projects and actions by SDGs

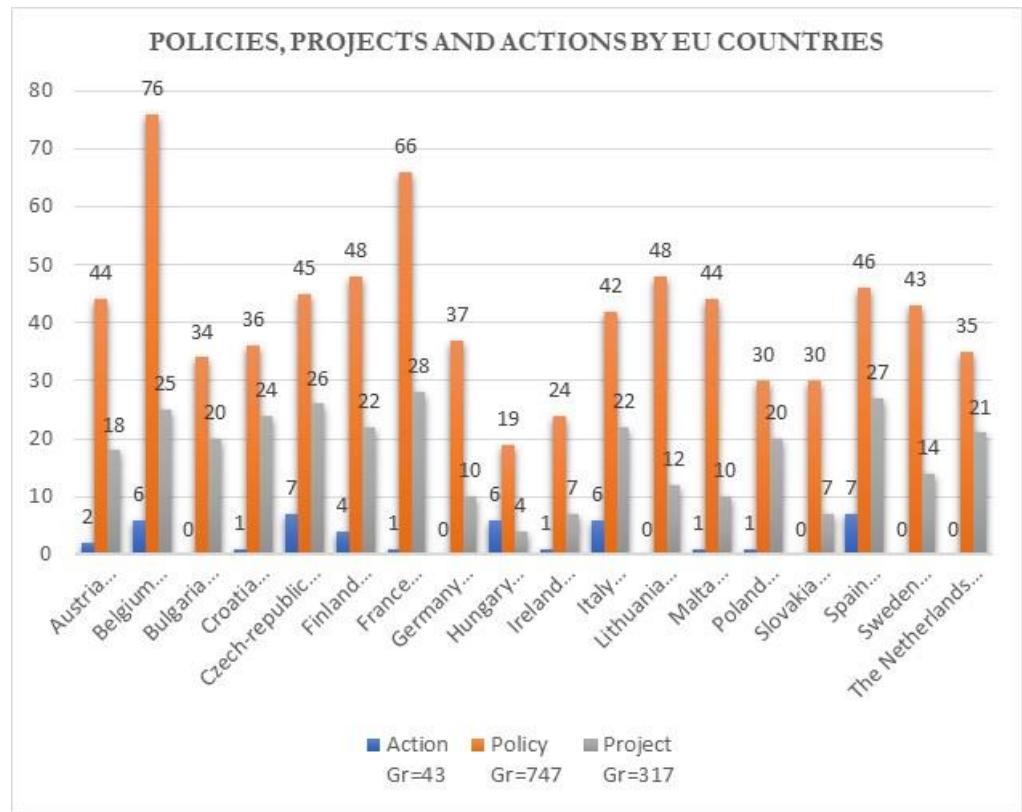

Figure 3: Policies, projects and actions by EU countries 
The most active countries in the EU in terms of SDGs and cultural policies are: France, Belgium, Spain, Italy and Finland. On the other hand, the countries with the least SDGs are Hungary and Ireland. Even so, we believe it is important to emphasize that all the analyzed countries comply with a minimum number of themes related to the SDGs. There is no country that does not include any of the concepts contained in the SDGs in its cultural policies (Fig. 4).

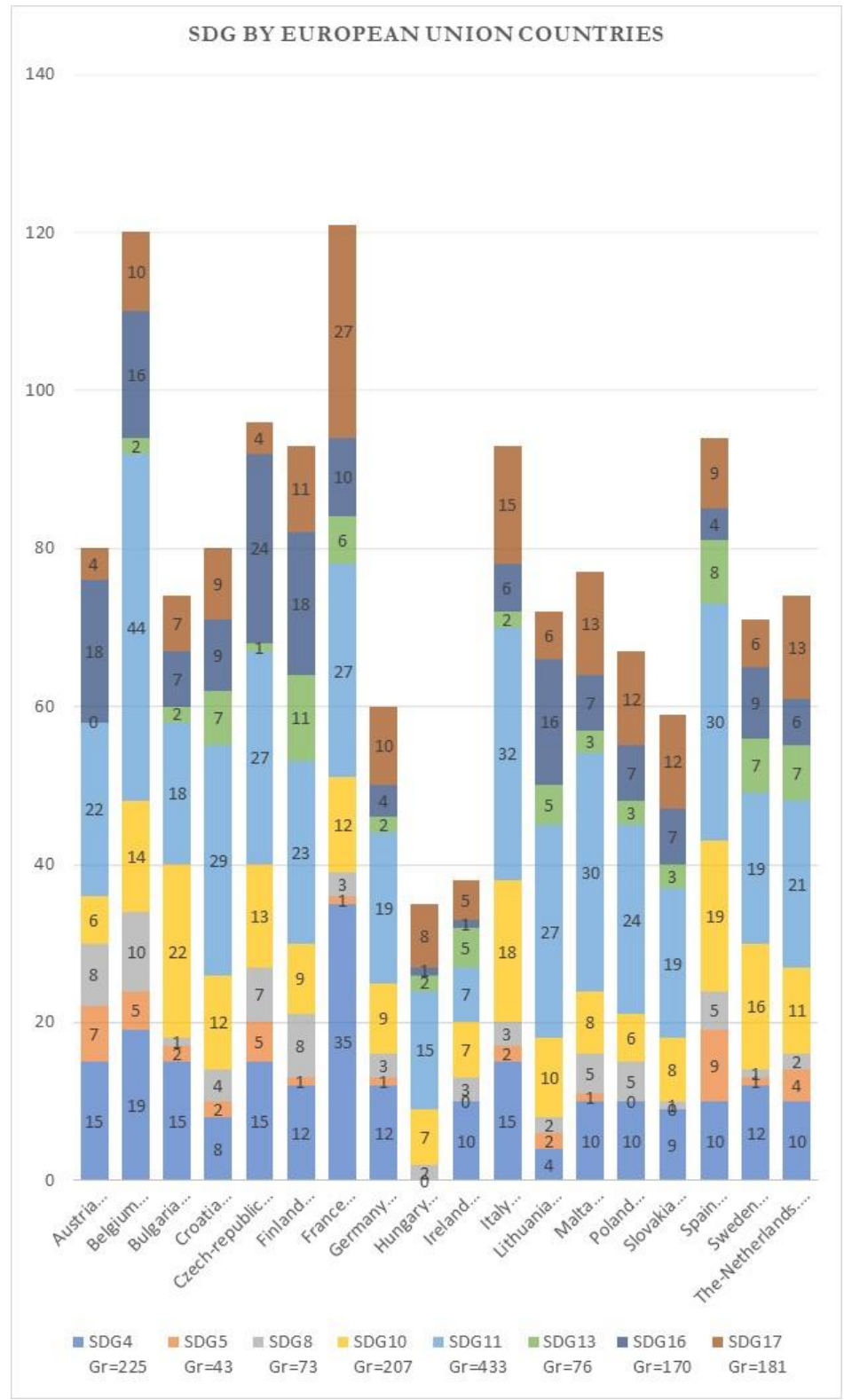

Figure 4: SDG by EU countries. 


\section{Discussion}

According to this research's results the cultural policies of the EU countries include the SDGs in a non-explicit way but referring to topics related to the 2030 Agenda (Table 3).

\section{Table 3: SDGs Targets included in the EU cultural policies SDG TARGET ASSOCIATED CONCEPT}

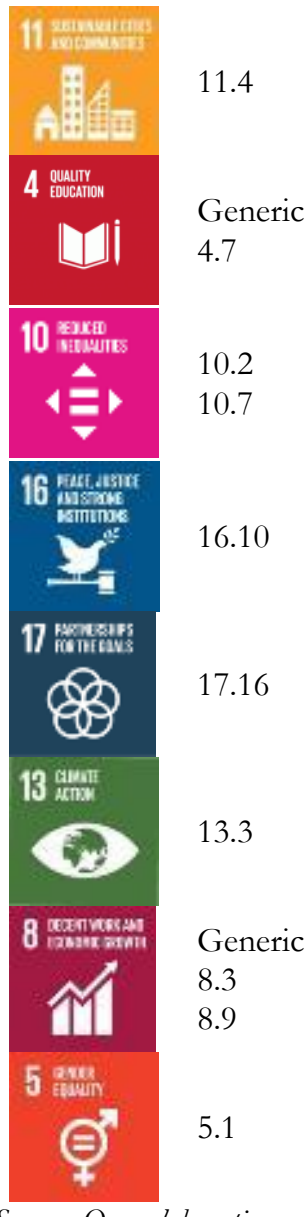

Protecting and preserving the natural and cultural heritage

Generic Ensuring inclusive and equitable quality education Cultural Diversity

Empowering and promoting social, economic and political inclusion for all

Facilitate orderly, safe and responsible migration and mobility of people

Ensure public access to information and protect fundamental freedoms

Partnerships to mobilize and share knowledge, skills, technology and financial resources to achieve the SDG

Improve education and raise human and institutional awareness to mitigate, adapt, reduce and anticipate the impact of climate change

Promote sustainable economic growth and decent work for all

Creativity and innovation

Promoting sustainable tourism

Source: Own elaboration

\section{SDG 11 Sustainable Cities and Communities}

SDG 11 aims to make cities inclusive, safe, resilient and sustainable (United Nations, 2016a).

The SDG 11 is the one that appears the most, in the analyzed EU countries cultural policies. The most active countries are Belgium, Italy, Spain and Malta. Proposals refers to protect and safeguard the world's cultural and natural heritage, For example, in the case of the Italian report: "Heritage has always been at the core of Italy's cultural policy" (Bodo \& 
Bodo, 2016).

\section{SDG 4 Quality Education}

The SDG 4 overall objective is to ensure quality and inclusive education for all and to promote lifelong learning. Education makes it possible to break the cycle of poverty, reduce inequalities and achieve gender equality, promote people's tolerance and contribute to the creation of peaceful societies. It also empowers people to live more healthily and sustainably (United Nations, 2020b).

SDG 4 is the second most represented, and the most active countries are France, Belgium, Austria, Czech Republic, Italy and Bulgaria. Often countries explicitly refer to the contribution of culture to SD through the concept of cultural diversity (Petrová, 2011).

\section{SDG 10 Reduce Inequalities}

SDG 10 aims to reduce inequalities in all countries. These inequalities are based on income, gender, age, disability, sexual orientation, race, class, ethnicity and religion; and they continue to persist around the world and in all countries. (United Nations, 2015).

SDG 10 is the third most represented and the most active countries in this aspect are Bulgaria, Spain, Italy and Sweden. The cultural policies analyzed are aimed at improving social cohesion, helping minority groups, groups with disabilities, and promoting cultural diversity and cohesion, such as the French example: "Yet, the role of culture as a factor of social cohesion is recognized as an essential fact in the cultural policies led in France at all territorial levels" (Ealth, 2016, pag.28); or the Spanish one: " The recognition of another form of cultural diversity beyond national borders was included in the cultural policy agendas, as part of the social integration of immigrant groups" (Villarroya \& Atecaamestoy, 2019).

\section{SDG 17 Partnerships for the Goals}

SDG 17 aims to revitalize global partnerships for SD. The Agenda 2030 claims governments, civil societies, scientists, academia and the private sector to work together for the SDGs achievement (United Nations, 2016b).

SDG 17 is the fourth most used, the most active countries on the SDG 17 are France, Italy, Malta and the Netherlands. Countries highlight the cooperation with the European Council, and other EU institutions, with projects such as the European Cultural Capital (Blumenreich, 2016).

\section{SDG 16 Peace, Justice and Strong Institutions}

SDG16 aims to promote peaceful and inclusive societies for SD, to provide access to justice for all and to build effective and inclusive institutions at all levels. (United Nations, 2019a).

SDG 16 is in the fifth place of the research results. The most active countries are the Czech Republic, Austria, Finland and Belgium. In the analyzed cultural policies, the focus is on the right to access to media, to digitized heritage and to cultural information. As an example, in Sweden: "One of the overall aims of measures taken by the Swedish government within the field of culture and media is to safeguard freedom of expression, accessibility and diversity of content" (Harding, 2017).

\section{SDG 13 Climate Action}

SDG 13 aims to urgently combat climate change and its impacts in order to build a sustainable world for all (United Nations, 2020a).

SDG 13 is the sixth most represented. Specifically, Finland is the country that offers the 
clearest example of relations between culture and climate change, since its cultural policy is strategically related to the environmental policies: "The goals of the cultural environment strategy have been crystallized into three viewpoints: cultural environment as an important resource, SD, and good administration" (Kanerva \& Mitchell, 2017).

\section{SDG 8 Decent Work and Economic Growth}

SDG 8 aims to promote inclusive and sustainable economic growth and to promote employment and decent work for all. Inclusive and sustainable economic growth leads to progress, the creation of decent jobs for all and the improvement of living standards for all people (United Nations, 2017).

SDG 8 is in seventh place of the analyzed data. The most active countries are Belgium, Austria and Finland. Policies related to this SDG focus on culture and creativity as tools for economic growth. (Attard, 2015). As an example, in Belgium: "The Walloon Region has set up this framework program to restructure, reinforce and modernize its economic fabric, by placing creativity and innovation at the heart of the Walloon project". Besides some regions highlight the importance of sustainable tourism based on culture as a source of sustainable growth (Rimkuté, 2020).

\section{SDG 5 Gender Equality}

SDG 5 aims to achieves gender equality and empowering women and girls around the world (United Nations, 2020c).

SDG 5 is in eighth position of relevance of the analyzed countries. The most active country is Spain, followed by Belgium and Austria, culture is seen as a tool for closing the gender gap (Villarroya \& Ateca-amestoy, 2019).

\section{Conclusions}

The overall results of this research show that the cultural policies of EU countries do include the UN 2030 Agenda SDGs, even if not explicitly. Specifically, we highlight 8 specific topics within the 17 SDGs indicators: Cultural and Natural Heritage (SDG 11), Cultural Education (SDG 4), Cultural Diversity (SDG 4), Social Inclusion (SDG 10), Access to Information (SDG 16), Cooperation with other Institutions (SDG 17), Environment (SDG 13), Economic Growth (SDG8) and Gender Equality (SDG 5).

Specifically, the research also confirms the theoretical framework defined by international organizations and academic studies (Dessein et al., 2015; Duxbury et al., 2017; Kangas et al., 2017b; Molina Neira, 2018; UNESCO, 2013, 2019b; Wiktor-Mach, 2018). It is confirmed that the SDGs topics are represented in the EU countries' cultural policies, but not explicitly mentioning each SDG or the Agenda 2030 framework (UNESCO, 2019a, p.11).

As a novelty for the sustainable cultural field, we found that the great majority of the proposals made by each country in its cultural policies are broadly theoretical and aspirational and have not put in practice yet. In this sense, the scope of these policies is in the theoretical stage rather than in their practical or tactical application, through long term projects. Policy makers should design their strategies with a more practical approach, through concrete projects, in order to speed the implementation of the SDGs in the cultural policies and, therefore, to promote the 2030 Agenda.

All the EU Countries, even if with a different approach and effort, are aligned with the 
Sustainable Development when talking about their culture and cultural strategy. The proposals of the EU's cultural policies are aligned on a number of specific common key topics. These are cultural and natural heritage, social inclusion, cooperation with other institutions, cultural education, cultural diversity, access to information, environment, economic growth and gender equality. This homogeneity should be taken as a positive proof of coordination and common objective within the EU.

Nevertheless, in order to achieve the objectives of cultural sustainability in the European Union within the framework of the 2030 Agenda, it is necessary to change the EU strategy, being more proactive in the effort to include culture in sustainable development. In this regard, although the "New European Agenda for Culture" was approved by the EU level in 2018, it only contains a paragraph stating that the European Commission intends to use this new Agenda to emphasize the cultural dimension of sustainable development and there is a weak focus on contributing to the implementation of the 2030 Agenda for Sustainable Development of the United Nations (Comisión Europea, 2018). No solid strategic contributions have been made to determine how to implement the 2030 Agenda in the cultural dimension. Despite the fact that the European cultural policy is align with several SDGs and it can contribute significantly to the achievement of these goals, as we have identified in this article, the European Union has not explicitly and proactively defined policies to foster the countries to pursuit these objectives.

According to the research results and the literature review, we propose some actions that UE could implement in order to promote cultural sustainability in the framework of the 2030 agenda. First, the EU should implement a common nomenclature that homogenize the cultural sustainability European dimensions in the 2030 Agenda framework. This will help the less advanced Countries to understand better how sustainability may affect positively the cultural environment.

Second, the EU should define priorities based on the most relevant SDGs for cultural sustainability. Some of these priorities will apply to the whole European Union and others, for example, will be very important for just some countries, as, for example, safeguard cultural heritage for the most touristic countries.

Finally, the EU should define some guidelines in order to help the states that are less advanced in the sustainability agenda to take as an example the best practices of the more advanced countries.

A first step into this direction, for example, example is the proposal made by the Culture Action Europe, Cultural Foundation and Europa Nostra (Cultural Action Europe et al., 2020) that propose a Cultural Pact for EU urging to all the EU Institutions, countries, regional and local authorities, civil society, cultural creative and heritage organizations to work together to find sustainable solutions for the future. This pact includes culture in the 2030 Agenda and the Green European Deal, creating a holistic strategy where culture is a cross-cutting multidimensional aspect of sustainability.

Thanks to these proactive actions the EU could be a pioneer and change agent in pursuing the 2030 Agenda Goals, in particular in the field of cultural sustainability, as, in the past, happened when the EU stated the pillars of the policies against the death penalty or about the consumer rights normative.

Besides, policy makers should communicate better these common proposals, in order to unify their strength and focus on these priorities reaching better results through 
cooperation and knowledge transfer and best practices sharing.

Our paper's main contribution is the confirmation that EU cultural policies do include the SDGs in their policies, projects and actions; and therefore, cultural sustainability has an active role in the development of sustainability, even if it is not done explicitly.

In future research we will focus on the study of the role of the cultural sustainability in the 2030 Agenda, specifically, developing the state of the art of this concept within the Sustainable Development (Dessein et al., 2015).

\section{Declaration of Conflicting Interests}

The authors declared no potential conflicts of interest with respect to the research, authorship, and/or publication of this article.

\section{Funding}

Susanna Ferran Vila acknowledges the partial award that covers the tuition fees of the third cycle studies to the Government of Andorra AMTCXXXX-AND/2020.

\section{References}

Alburquerque Llorens, F. (2019). La localización de los objetivos de desarrollo sostenible y la financiación de la Agenda 2030: el discurso y la realidad. Revista de Fomento Social, 1(2019), 77-104. https://doi.org/10.32418/rfs.2019.293.1538

Alhaddi, H. (2015). Triple Bottom Line and Sustainability : A Literature Review. Business and Management Studies, 1(2), 6-10. https://doi.org/10.11114/bms.v1i2.752

Asikainen, S., Brites, C., Plebanczyk, K., Rogac mitjatovic, L., \& Soini, K. (2017). Culture in Sustainability, towards a transdiscip (Sophi (ed.)). www.jyu.fi

Astara, O. H. (2014). Culture as the Fourth Pillar of Sustainable Development. Sustainable Development, Culture, Traditions, 1(2), 28-40. https://doi.org/10.14217/smalst-2007-3-en

Attard, A. (2015). Country Profile Malta (Issue November). www.culturalpolicies.net

Baltà Portolés, J., \& Dragićevic Šešić, M. (2017). Cultural rights and their contribution to sustainable development: implications for cultural policy. International Journal of Cultural Policy, 23(2), 159-173. https://doi.org/10.1080/10286632.2017.1280787

Barker, V. (2019). The democratic development potential of a cultural ecosystem approach. The Journal of Law, Social Justice and Global Development, 24, 86-99. https://doi.org/10.31273/lgd.2019.2405

Bervar, M. (2019). Importance of Culture for Sustainable Development. Managing Global Transitions, 17(3), 195209. https:/ / doi.org/10.26493/1854-6935.17.195-209

Beyne, J. (2020). Designing and implementing sustainability: An integrative framework for implementing the sustainable development goals. European Journal of Sustainable Development, 9(3), 1-12. https://doi.org/10.14207/ejsd.2020.v9n3p1

Blumenreich, M. U. (2016). Country Profile Germany https://www.culturalpolicies.net/down/germany_012016.pdf

Bodo, C., \& Bodo, S. (2016). Counmtry profiel Itlay. www.culturalpolicies.net

Boekman Foundation. (2020). Compendium Cultural policies \& trends. https://www.culturalpolicies.net/about/

Brundtland, G., Khalid, M., Agnelli, S., Al-Athel, S., Chidzero, Bernard Fadika, L., Hauff, V., Lang, I., Shijun, M., Morino de Botero, M., Singh, M., \& Okita, S. (1987). Our Common Future -Brundtland report.

Comisión Europea. (2018). Una nueva Agenda europea para la cultura. https://eur-lex.europa.eu/legalcontent/ES/TXT/PDF/?uri=CELEX:52018DC0267\&from=EN

Council of the European Union. (2019). Cultural dimension of Sustainable Development. https://doi.org/10.1017/CBO9781107415324.004 
Council of the European Union. (2020). Open Method Coordination Group on Cultural Dimension of Sustainable Development.

Cultural Action Europe, European Cultural Foundation, \& Europa Nostra. (2020). Deal for Europe A Central place of Culture. https:/ / cultureactioneurope.org/files/2020/11/statement-Final-1.pdf

Culture Action Europe. (2017). The role of culture in Agenda 2030 A European cultural fund for sustainability Action: https://cultureactioneurope.org/files/2019/09/Implementing-Culture-in-SustainableDevelopment-Goals-SDGs.pdf

Dessein, J., Soini, K., Fairclough, G., \& Horlings, L. (2015). Culture in , for and as Sustainable Development. Conclusions fromm the COST Action IS1007 Investigating Cultural Sustainability (U. of Jyväskylä (ed.)).

Duxbury, N., Kangas, A., \& De Beukelaer, C. (2017). Cultural policies for sustainable development: four strategic paths. International Journal of Cultural Policy, 23(2), 214-230. https://doi.org/10.1080/10286632.2017.1280789

Ealth, P. U. H. (2016). Country: FRANCE （2016） (Issue February). www.culturalpolicies.net

Elkinjton, J. (1998). Partnerships from Cannibals with Forks: The Triple iottom line of 21 st = Century Business. Environmental Quality Management, 37-51.

Erlewein, S.-N. (2017). Culture, Development and Sustainability: The cultural impact of development and Culture's role in sustainability. In M.-T. Albert, F. Bandarin, \& A. Pereira Roders (Eds.), Going Beyond. Heritage Studies No. 2. Springer International Publishing. https://doi.org/10.1007/978-3-319-571652

Errichiello, L., \& Micera, R. (2018). Leveraging smart open innovation for achieving cultural sustainability: Learning from a New City Museum Project. Sustainability (Switzerland), 10(6). https://doi.org/10.3390/su10061964

Friese, S. (2011). Using ATLAS.ti for Analyzing the Financial Crisis Data 1 . Introduction and Underlying Assumptions. Forum: Qualitative Social Research, 12(1), 1-24.

General Assembly of United Nations. (2015). Transforming our world: the 2030 Agenda for Sustainable Development. Resolution Adopted by the General Assembly on 25 September 2015.

Gusmão Caiado, R. G., Leal Filho, W., Quelhas, O. L. G., Luiz de Mattos Nascimento, D., \& Ávila, L. V. (2018). A literature-based review on potentials and constraints in the implementation of the sustainable development goals. Journal of Cleaner Production, 198, 1276-1288. https://doi.org/10.1016/j.jclepro.2018.07.102

Harding, T. (2017). Country Profile SWEDEN (Issue November 2016). www.culturalpolicies.net

Hawkes, J. (2001). The foruth pillar of Sustainability. Culture' $s$ essential role in public planning. http://community.culturaldevelopment.net.au//Downloads/HawkesJon(2001)TheFourthPillarOf Sustainability.pdf

Holton, J., \& Walsh, I. (2017). Classic grounded Theory, applications with qualitative \& quantitative data. SAGE Publications, Inc.

Horne, J., Recker, M., Michelfelder, I., Jay, J., \& Kratzer, J. (2020). Exploring entrepreneurship related to the sustainable development goals - mapping new venture activities with semi-automated content analysis. Journal of Cleaner Production, 242, 118052. https://doi.org/10.1016/j.jclepro.2019.118052

International Journal of Cultural Policy. (2020). Aims and Scope.

Isar, Y. R. (2017). 'Culture', 'sustainable development' and cultural policy: a contrarian view. International Journal of Cultural Policy, 23(2), 148-158. https://doi.org/10.1080/10286632.2017.1280785

Jeannotte, M. S. (2017). Caretakers of the Earth: integrating Canadian Aboriginal perspectives on culture and sustainability into local plans. International Journal of Cultural Policy, 23(2), 199-213. https://doi.org/10.1080/10286632.2017.1280784

Kagan, S., Hauerwaas, A., Holz, V., \& Wedler, P. (2018). Culture in sustainable urban development: Practices and policies for spaces of possibility and institutional innovations. City, Culture and Society, 13(August), 32-45. https://doi.org/10.1016/j.ccs.2017.09.005

Kanerva, A., \& Mitchell, R. (2017). Country profile FINLAND (Issue March). https://www.culturalpolicies.net/database/

Kangas, A., Duxbury, N., \& De Beukelaer, C. (2017a). Introduction: cultural policies for sustainable development. International Journal of Cultural Policy, 23(2), 129-132. https://doi.org/10.1080/10286632.2017.1280790 
Loach, K., Rowley, J., \& Griffiths, J. (2017). Cultural sustainability as a strategy for the survival of museums and libraries. International Journal of Cultural Policy, 23(2), 186-198. https://doi.org/10.1080/10286632.2016.1184657

Luque Gallegos, V. (2015). Cultura y Desarrollo Sostenible. Periferica, 16, 51-61. https://doi.org/10.25267/Periferica.2015.116.05

Martinell, A. (2020). Cultura y Desarrollo Sostenible, Aportaciones al debate sobre la dimensión cultural de la Agenda 2030. Periferica, 16, 51-61. https://doi.org/10.25267/Periferica.2015.i16.05

Maxwell, R., \& Miller, T. (2017). Greening cultural policy. International Journal of Cultural Policy, 23(2), 174-185. https://doi.org/10.1080/10286632.2017.1280786

Miotto, G., Blanco-González, A., \& Díez-Martín, F. (2020). Top business schools legitimacy quest through the Sustainable Development Goals. Heliyon, 6(11), e05395. https://doi.org/10.1016/j.heliyon.2020.e05395

Miotto, G., Polo López, M., \& Rom Rodríguez, J. (2019). Gender Equality and UN Sustainable Development Goals: Priorities and Correlations in the Top Business Schools' Communication and Legitimation Strategies. Sustainability, 11(2), 302. https://doi.org/10.3390/su11020302

Molina Neira, B. A. (2018). La incorporación de la cultura y el patrimonio en el desarrollo sostenible: desafíos y posibilidades. Revista Humanidades, 8(1), 1-33. https://doi.org/10.15517/h.v8i1.31465

Noguero, F. L. (2002). El análisis de contenido como método de investigación. Revista de Educación, 4(2002), 167-179. https://doi.org/ISSN-e 1575-0345

Nurse, K. (2006). Culture as the fourth pilar of sustainable development (Vol. 5, Issue June, pp. 51-61).

Olabuénaga, J. I. R. (2012). Metodología de la investigación (5a). Universidad de Deusto.

Petrová, P. (2011). Country Profile Czech Republic. In Europe (Issue November). https://www.culturalpolicies.net/database/

Petti, L., Trillo, C., \& Makore, B. N. (2020). Cultural Heritage and Sustainable Development Targets: A Possible Harmonisation? Insights from the European Perspective. Sustainability, 12(3), 926. https://doi.org/10.3390/su12030926

Piñuel Raigada, J. L. (2002). Epistemología, metodología y técnicas del análisis de contenido. Estudios de Sociolinguistica, 3(1), 1-42.

Rayman-Bacchus, L., \& Radavoi, C. N. (2019). Advancing culture's role in sustainable development: social change through cultural policy. International Journal of Cultural Policy, 1-19. https://doi.org/10.1080/10286632.2019.1624735

Rimkuté, A. (2020). Country profile guide Lithuania. www.culturalpolicies.net

Sabatini, F. (2019). Culture as Fourth Pillar of Sustainable Development: Perspectives for Integration, Paradigms of Action. European Journal of Sustainable Development, 8(3), 31. https://doi.org/10.14207/ejsd.2019.v8n3p31

Sachs, J. D., Schmidt-Traub, G., Mazzucato, M., Messner, D., Nakicenovic, N., \& Rockström, J. (2019). Six Transformations to achieve the Sustainable Development Goals. In Nature Sustainability (Vol. 2, Issue 9). https://doi.org/10.1038/s41893-019-0352-9

Saito, O., Managi, S., Kanie, N., Kauffman, J., \& Takeuchi, K. (2017). Sustainability science and implementing the sustainable development goals. Sustainability Science, 12(6), 907-910. https://doi.org/10.1007/s11625-017-0486-5

Sanahuja, J. A., \& Vázquez, S. T. (2017). From millennium to sustainability: Challenges and prospects of the 2030 agenda for sustainable development [Del milenio a la sostenibilidad: Retos y perspectivas de la Agenda 2030 para el desarrollo sostenible]. Politica y Sociedad, 54(2), 521-543. https://doi.org/10.5209/POSO.51926

Soini, K., \& Dessein, J. (2016). Culture-Sustainability Relation: Towards a Conceptual Framework. Sustainability, 8(167), 13-15. https://doi.org/10.3390/su8020167

Streimikiene, Mikalauskiene, \& Kiausiene. (2019). The Impact of Value Created by Culture on Approaching the Sustainable Development Goals: Case of the Baltic States. Sustainability, 11(22), 6437. https://doi.org/10.3390/su11226437

Swanson, K. K., \& DeVereaux, C. (2017). A theoretical framework for sustaining culture: Culturally sustainable entrepreneurship. Annals of Tourism Research, 62, 78-88. https://doi.org/10.1016/j.annals.2016.12.003

Throsby, D. (2017a). Culturally sustainable development: theoretical concept or practical policy instrument? International Journal of Cultural Policy, 23(2), 133-147. https://doi.org/10.1080/10286632.2017.1280788

Tollin, K., \& Christensen, L. B. (2019). Sustainability Marketing Commitment: Empirical Insights About Its Drivers at the Corporate and Functional Level of Marketing. Journal of Business Ethics, 156(4), 11651185. https://doi.org/10.1007/s10551-017-3591-6 
Trinidad-Requena, A., Carrero-Planes, V., \& Soriano-Miras, R. M. (2006). Teoría Fundamentada "Grounded Theory". La construcción de la teoría a través del análisis interpretacional. Cuadernos Metodológicos.

Turner, M. (2017). Culture as an enabler for sustainable development: Challenges dor the World Heritage Convention in Adopting the UN Sustainable Development Goals. Going Beyond. Heritage Studies No. 2, Hawkes 2001, 59-69. https://doi.org/10.1007/978-3-319-57165-2

UCLG. (2015). Cultura 21:Accions. http://www.agenda21culture.net/es

UNESCO. (2013). Declaración de Hangzhou Situar la cultura en el centro de las políticas de desarrollo sostenible. 1-6.

UNESCO. (2018). Culture for the 2030 Agenda. https://unesdoc.unesco.org/ark:/48223/pf0000264687

UNESCO. (2019a). Culture and Public Policy for Sustainable Development. https://doi.org/10.1596/0-8047-4787-3

UNESCO. (2019b). Thematic Indicators for Culture in the 2030 Agenda. https://whc.unesco.org/en/culture2030indicators/

United Nations. (2015). Goal 10 Why it matters. In Journal of the United Nation (Vol. 140, Issue 7, p. 9). https://www.un.org/sustainabledevelopment/wp-content/uploads/2018/01/10_Why-It-Matters2020.pdf

United Nations. (2016a). Goal 11: Make cities inclusive, safe, resilient and sustainable. In Journal of the United Nation. http://www.un.org/sustainabledevelopment/cities/

United Nations. (2016b). Goal 17 Partnerships: Why they matter. In Journal of the United Nation. https://www.un.org/sustainabledevelopment/wp-content/uploads/2019/07/17_Why-It-Matters2020.pdf

United Nations. (2016c). The 2030 Agenda for Sustainable Development (pp. 12-14). https://doi.org/10.1201/b20466-7

United Nations. (2017). Goal 8 Decent work and economic growth. In Journal of the United Nation (pp. 34-35). https://doi.org/10.18356/225e035f-en

United Nations. (2019a). Peace, justice and strong institutions. Journal of the United Nation, 54-55. https://doi.org/10.18356/ad09e0ad-en

United Nations. (2019b). Report of the Secretary-General on SDG Progress 2019 Special Edition. https://sustainabledevelopment.un.org/content/documents/24978Report_of_the_SG_on_SDG _Progress_2019.pdf

United Nations. (2020a). Goal 13 To limit global warming climate action: carbon emissions need to fall 45 per cent. In Journal of the United Nation. https://www.un.org/sustainabledevelopment/wpcontent/uploads/2019/07/13_Why-It-Matters-2020.pdf

United Nations. (2020b). Goal 4 quality education: and in reading. In Journal of the United Nation. https://www.un.org/sustainabledevelopment/wp-content/uploads/2017/02/4_Why-It-Matters2020.pdf

United Nations. (2020c). Goal 5 gender equality : women 27 per cent positions. In Journal of the United Nation. https://www.un.org/sustainabledevelopment/wp-content/uploads/2016/08/5_Why-It-Matters2020.pdf

United Nations. (2020d). Informe de los Objetivos de Desarrollo Sostenible 2020. In Informe de los Objetivos de Desarrollo Sostenible 2020. https://unstats.un.org/sdgs/files/report/2018/TheSustainable DevelopmentGoalsReport2018-ES.pdf

Villarroya, A., \& Ateca-amestoy, V. (2019). Country profile Spain (Issue February). www.culturalpolicies.net

Wiktor-Mach, D. (2018). What role for culture in the age of sustainable development? UNESCO's advocacy in the 2030 Agenda negotiations. International Journal of Cultural Policy. https://doi.org/10.1080/10286632.2018.1534841

Xuereb, K. (2018). The Impact of the European Union on Cultural Policy in Malta. Croatian International Relations Review, 24(82), 38-61. https://doi.org/10.2478/cirr-2018-0009 